Tropical Journal of Pharmaceutical Research, December 2009; 8 (6): 557-566

(C) Pharmacotherapy Group, Faculty of Pharmacy, University of Benin Benin City, 300001 Nigeria.

All rights reserved.

Research Article

Available online at http://www.tjpr.org

\title{
Pharmacognostic Investigation of the Leaves and Stems of Viburnum erubescens Wall.ex DC
}

\author{
K Prabhu ${ }^{*}$, PK Karar ${ }^{1}$, K Ponnudurai ${ }^{1}$ and S Hemalatha ${ }^{2}$ \\ ${ }^{1}$ Department of Pharmacognosy, Nandini Nagar Mahavidyalaya College of Pharmacy, Nawabganj - 271303, Gonda, \\ ${ }^{2}$ Department of Pharmaceutics, IT-Banaras Hindu University, Varanasi - 221005, Uttar Pradesh, India.
}

\begin{abstract}
Purpose: Some pharmacognostical investigations were carried out on the leaves and stems of Viburnum erubescens Wall.ex DC to record parameters for identifying and differentiating various species of Viburnum.

Methods: The research specimens were authenticated and preserved both in fresh and dry forms. The leaves and stems were morphologically screened followed by anatomical studies with the aid of Labphot 2 microscopic units. Powder microscopy and micrometric studies, including leaf constants, were performed using suitable tools and reagents under different magnifications. Physicochemical parameters such as alcohol and aqueous extractive values, ash values, crude fibre content for stem, and fluorescence properties were also determined. The specimens were subjected to successive extraction processes by Soxhlet method using solvents of increasing polarity. Qualitative chemical screening tests with suitable reagents were also undertaken.

Results: The leaves were petiolate and opposite, acuminate apex with unequal base, abaxial surfaces which turned blackish on storage, and had irritant smell with a slightly bitter taste. The vein islets were squarish and polygonal. Trichomes and club-shaped glandular trichomes were evident. The barks were hard and brittle with abundant fissures. The periderm was four-layered followed by homogenous parenchyma. The phloem region appeared with sclerenchyma elements; libriform fibres and tanniferous cells were also evident. The presence of phytosterols, triterpenoids, glycosides (saponins) and phenolic compounds (flavonoids and procyanidins) was positive for both the leaf and the stem.

Conclusion: The findings of this study could be useful in identifying Viburnum species, both in whole and powder form. Also, the parameters derived from this study may be useful in differentiating this species from the rest of its relatives.
\end{abstract}

Keywords: Pharmacognostic investigation; Amoeboid; Caprifoliaceae; Libriform; Stone cells; Viburnum erubescens 


\section{INTRODUCTION}

The order, Dipsacales, comprises of three families, namely, Dipsacaceae, Veleriaceae and Caprifoliaceae (Viburnaceae). The family, Caprifoliaceae, constitutes about 12 genera and 450 species. The genus, Viburnum, is one of the 12 genera covering about 200 species found across the world. The current study focuses on one of the 200 species, namely, Viburnum erubescens Wall.ex DC. The genus, Viburnum Linn., under the family Caprifoliaceae contains about 17 species distributed across India [1]. Several species under the genus have been screened and are reported to contain bioactive chemical constituents such as triterpenoids, saponins, glycosides, tannins and other poly phenolic compounds and phytosterols [2]. However, limited members of the genus have been subjected to pharmacological investigations. These include the soluble and insoluble fractions of the ethylacetate extracts of stem, root and bark of Viburnum coriaceum which exhibited antispasmodic activity; ethanol extract of aerial parts possessed antiprotozoal activity against Entamoeba histolytica; antiviral activity of $50 \%$ ethanol extract of the entire plant of Viburnum erubescens; alcohol extracts of the stem and root bark of Viburnum foetidum exhibited antispasmodic effect [3]; Viburnum obovatum bark showed uterine sedative activity; stem bark of Viburnum opulus displayed uterine relaxant activity, and astringent effect; barks of Viburnum prunifolium showed activity against smooth muscle spasm [3].

Based on the foregoing, the present study entails the pharmacognostic investigation of the leaves and stem of Viburnum erubescens, with a view to providing pertient information/data on its identification, chemical elaboration and pharmacological potential. To the best of our knowledge, this is the first time a pharmacognostic study has been undertaken on this species. Findings from this study would be useful as standards for the species as well as a source of reference for further scientific investigation of the species.

\section{EXPERIMENTAL}

\section{Collection of specimens}

The plant specimens for the study were collected from Nilgiri Hills, Tamil Nadu, India, and authenticated by $\mathrm{Dr} \mathrm{V}$ Chelladurai, former Professor of Botany, Medicinal Plant Survey for Siddha, Government of India, as Viburnum erubescens Wall.ex DC. A voucher specimen (VE131) was deposited in the herbal museum at Nandini Nagar Mahavidyalaya College of Pharmacy, Uttar Pradesh. Care was taken to select healthy plants for the study. The plant parts for the study were collected fresh from the plant and placed in FAA (formalin : acetic acid : $70 \%$ ethyl alcohol) in a ratio of $1: 1: 18$. Twenty four hours later, the specimens were dehydrated with a graded series of tertiary-butyl alcohol (TBA). Infiltration of the specimens was carried out by gradual addition of paraffin wax (melting point $58-60^{\circ} \mathrm{C}$ ) until TBA solution attained supersaturation. The specimens were then cast into paraffin blocks.

\section{Sectioning}

The paraffin-embedded specimens were sectioned with the aid of an MC 930 advanced precision rotary microtome. The thickness of the sections was $10-12 \mu \mathrm{m}$. Dewaxing of the sections was performed by treating the specimen shides sequentially with xylol, xylol + alcohol, alchol, water and finally, with staining fluid [4. Wherever necessary, sections were also stained with safranin, fast-green and iodine in potassium iodide in order to evaluate starch, stomatal morphology, veination pattern, and trichome presence and distribution. Either paradermal sections (sections taken parallel to the leaf surface) were prepared and cleaned with $5 \%$ sodium hydroxide, or epidermal peeling after partial maceration employing Jeffrey's maceration fluid [5] were prepared. Glycerinmounted temporary preparations were made 
for macerated/cleared materials. Powdered materials of different parts were cleared with $\mathrm{NaOH}$ and mounted in glycerin after staining with toluidine blue. Different components were studied and measured as indicated below.

\section{Microscopic examination}

With the aid of a compund microscope (Focus (ISI), JPM-1, India) and an eye-piece micrometer calibrated with a stage micrometer, the individual character of each specimen was studied under both low- $(10 \mathrm{x} \times$ $10 x)$ and high-power (10x $x$ 45x) magnification.

\section{Powder microscopy}

The leaves were dried for a minimum of 15 days under a shade, powdered and screened through sieves with aperture size of $180 \mu \mathrm{m}$ and $125 \mu \mathrm{m}$ separately to obtain fine and very fine powders, respectively, and then subjected to microscopic examination. The specimens were treated with the following reagents in order to evaluate components of diagnostic value: $50 \%$ glycerin as temporary mountant; $2 \%$ phloroglucinol in a mixture of $90 \%$ ethanol and conc. $\mathrm{HCl}(1: 1)$ for lignin; 5 $\%$ alcoholic ferric chloride for phenolic compounds; $2 \%$ iodine solution for starch grains; and $0.08 \%$ ruthenium red in $10 \%$ lead acetate for mucilage [14].

\section{Photomicrography}

Photomicrographs were taken in addition to microscopic examination, where necessary, at different magnifications using a Nikon Labphot 2 microscope. For normal observations, a bright field was used while for the study of calcium oxalate crystals, starch grains and lignified cells, polarized light was employed. Since these structures have birefringent properties under polarized light, they appear bright against dark background. Magnifications of the figures were indicated by scale-bars $[6,7]$.

\section{Numerical and physical standards}

\section{Determination of extractives}

Approximately $5 \mathrm{~g}$ of the air-dried crude drug was macerated with $100 \mathrm{ml}$ of the solvents for $24 \mathrm{~h}$. After filtration, $25 \mathrm{ml}$ of the filtrate was evaporated to dryness and the percentage of extractives was calculated with reference to the air-dried drug [8].

\section{Determination of ash values}

Approximately $3 \mathrm{~g}$ of the air-dried crude drug was incinerated in a tared silica crucible (Vitrosil, India) in a furnace at a temperature not exceeding $450{ }^{\circ} \mathrm{C}$ until free from carbon. It was washed in hot water to exhaust the charred mass, and the residue was incinerated on an ashless filter paper and weighed. Further treatment was carried out to derive water soluble, acid insoluble and sulphated ash values [8].

\section{Histochemical studies}

Histochemical analysis was carried out on the specimens using, separately, dilute iodine solution, Lacto-phenol, Dragendorff"s reagent, dilute ferric chloride solution and phloroglucinol + HCL (1:1). The reagenttreated hard section of the plant tissue was observed and microscope to detect the presence of histochemical components [9].

\section{Fluorescence studies}

Fluorescence analysis was carried out in an ultraviolet cabinet (MAC, MSW-508, Long UV,India) at $365 \mathrm{~nm}[10]$.

\section{Micrometric studies}

Micrometric evaluation (including assessment of leaf constants) was carried out with the aid of a compound microscope fitted with a camera (Swift Ive's) as described elsewhere [11-13]. 


\section{Preliminary screening for foreign matter}

The shade-dried leaves were ground to a moderately coarse powder in a mechanical grinder. Aprrox. $100 \mathrm{~g}$ of the powder was extracted successively with petroleum ether $\left(60-80^{\circ} \mathrm{C}\right)$, benzene, chloroform and ethanol (95\%) using a Soxhlet apparatus. Each solvent extraction was carried out for 24 h. Finally, the marc left was extracted with water by digesting over a boiling water bath. The extraction was continued until a few drops of the last portion of the extract left no residue on drying. The extracts were taken in a tarred porcelain dishes, evaporated to dryness over a water bath and dried in an oven at $105^{\circ} \mathrm{C}$ to a constant weight. The extractives (\%) were calculated with reference to the air-dried drug [15].

\section{RESULTS}

\section{Macroscopic characteristics of the leaf and stem}

The leaves were of opposite, petiolate, ovate to narrow oblong, serrulate accuminate and with unequal base. The dried leaves were yellowish green above and pale green below; midrib raised below and flat above; about $4-$ 7 pairs of primary veination, extended up to the margin; the petiole conical being $0.5-1.5$ $\mathrm{cm}$ long and $0.3-1 \mathrm{~mm}$ wide. The leaves were $3.5-8.5 \mathrm{~cm}$ in length and $2.5-5 \mathrm{~cm}$ in width. The adaxial surface was smooth and slippery unlike the abaxial side. The dried leaves had an irritant odour and were slightly bitter in taste. Some leaves on storage turned blakish on their adaxial surface. The petiole showed parallel and lateral wings.

The outer bark was blackish-brown in colour while the inner bark was dark brown with abundant fissures which were irregular and longitudinal. The bark peeled from a twig measured $0.5-2 \mathrm{~mm}$ in thickness and were hard and brittle; the broken surface showed the remains of fibres which were odourless and tasteless.
Special features: The outer bark contained smooth and powdery surface on drying. The wood was reddish-yellow in colour, flexible and extremely hard. The broken surface showed the remains of the fibres and the wood had a characteristic odour with no specific taste. The stem, which measured more than $1 \mathrm{~cm}$ in thickness, showed a central brown pith.

\section{Microscopy of the leaf}

The results from polychromatic staining with toluidine blue showed that the dye imparted pink color to the cellulose walls, blue to the lignified cells, dark green to suberin, violet to the mucilage and blue to the protein bodies.

The leaf has a dorsiventral symmetry with fairy prominent midrib. The midrib is planoconvex with semicircular abaxial part. The midrib is $300 \mu \mathrm{m}$ thick and $440 \mu \mathrm{m}$ wide. The adaxial epidermal layer of the midrib is pappillate and thin-walled. The palisade zone does not extend across the adaxial part of the midrib and the vascular bundle is embedded in the ground tissue. The ground tissue is four- or five-layered, parenchymatous and thin-walled. The vascular strand is single, prominent, semicircular and collateral. It is $200 \mu \mathrm{m}$ wide and consists of several parallel lines of xylem elements and a narrow abaxial phloem. The xylem elements are angular, wide and thin-walled.

The lamina is smooth and even. It has bilateral structure with differentiation of mesophyll tissues. The adaxial epidermis is wide, thin-walled and rectangular, and measured $20 \mu \mathrm{m}$ in thickness. The abaxial epidermis is narrow and $10 \mu \mathrm{m}$ thick. The cells are cylindrical and thin walled and mucilage oozes from the walls. The lamina is $120 \mu \mathrm{m}$ thick. These are two layers of short, vertically elongated compact palisade cells and four layers of large, lobed, and loosely arranged spongy parenchyma cells (Figure $1)$. 
The leaf margin is blunt and semicircular; the epidermal cells along the margins are radially along and papillate. Two or three subepidermal layers of compact thick-walled cells and prominent mass of sclerenchyma cells are seen within the marginal portion.

The leaf petiole is plano-convex with two lateral, thick wings towards the adaxial part.
The adaxial side is flat and even; the abaxial part is semicircular and wide. The petiole is $1.5 \mathrm{~mm}$ thick and $1.8 \mathrm{~mm}$ wide. The epidermal layer is thin with small squarish cells. The ground tissue is homogenous, parenchymatous, thin-walled, circular and compact.

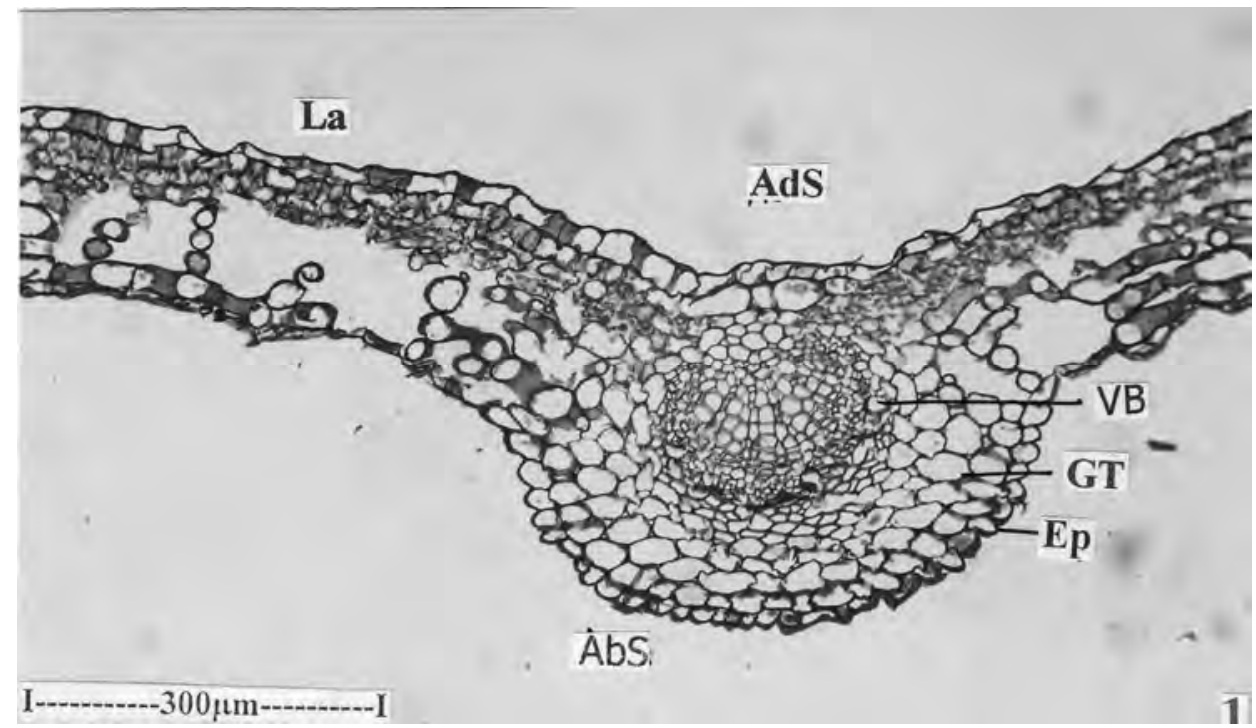

Figure 1: Anatomy of the leaf - Transverse section of leaf through midrib ( Abaxial side( AbS); Adaxial side(Ads); Epidermis(Ep); Ground tissue(GT); Lamina(La); Vascular bundle(VB))

The vascular cylinder is hollow and wide triangular in outline; it is $900 \mu \mathrm{m}$ in horizontal plane and $600 \mu \mathrm{m}$ in vertical plane. The xylem cylinder has closely arranged radial files of narrow angular xylem elements and outer cylinder of phloem. Some of the cells in phloem are dilated, having tannin contents (Figure 2).

The wings are thick and bluntly conical, measuring $500 \mu \mathrm{m}$ in thickness and $600 \mu \mathrm{m}$ in length. They have compact thin-walled parenchymatous ground tissue and one or two vascular strands; the strands are planoconvex in outline and have a few lines of xylem and thin lines of phloem.

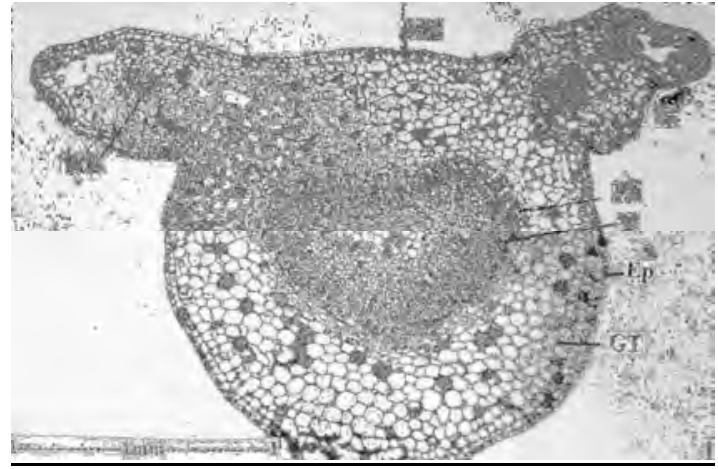

Figure 2: Anatomy of the petiole - Transverse section of petiole (entire view) (AdS = adaxial side; $E p=$ epidermis; $G T=$ ground tissue; $P h=$ phloem; $W=$ wing; $W B=$ wing bundles; $X=x y l e m$ ) 
The adaxial epidermis is non-stomatiferous. The cells are amoeboid in outline and the anticlinal walls are fairly thick and waxy. The abaxial epidermis is stomatiferous while the ground cells are prominent and elliptical. The stomata type is anomocytic and no distinct subsidiary cells are evident. The epidermal cells are rare, comparatively thin-walled and amoeboid in outline. The epidermal cells have prominent nuclei.

The vein-islets are distinct. They are squarish or polygonal, thick, simple or forked once or twice. Epidermal trichomes are also evident on the surface of the epidermis. The trichomes are unicellular, unbranched, thick walled and pointed. The trichomes are mostly curved.

\section{Stem and stem bark}

The stem is circular and even. It has a narrow, superficial and continuous periderm. The periderm is three- or four-layered with a distinct phellogen and outer tabular, suberised phellem. Phelloderm is not evident. Total width of the periderm is uniformly $70 \mu \mathrm{m}$ all around. The cortical zone is wide with uniform width; it is homogenous and parenchymatous; the cells are circular and compact. The cortical zone is $200 \mu \mathrm{m}$ wide. The phloem is narrow and continuous around the xylem circumference. The outer boundary of the phloem has a layer of sclerenchyma elements. The xylem cylinder is $400 \mu \mathrm{m}$ thick and consists of narrow, angular, thin-walled vessels, thick-walled lignified fibres and narrow rays. The pith is wide, circular and consists of intact, thin-walled, circular and compact cells. Some of the cells have dense tannin content.

The stem bark has a wide, homogenous periderm with smooth surface. It consists of outer wide phellem with regular radial rows of tabular suberised cells. The phellem zone is $500 \mu \mathrm{m}$ wide. The phelloderm is distinct and has $10-15$ layers of tabular cells with cell content. The phelloderm merges with the cortical zone where large masses of sclereids are scattered in the parenchymatous ground tissue. The sclereids are brachy-sclereid (stone cells) type, and they are isodiametric and polyhedral; their walls are heavily thick and lignified; narrow canal-like simple pits are abundant on their walls. The cell lumen is wide, often filled with tannin. Calcium oxalate crystals are widespread in the parenchyma cells. Inner to the cortex is a wide zone of secondary phloem. Secondary phloem is differentiated into outer wider zone of collapsed cells with irregular masses of sclereides and crushed phloem elements. The collapsed phloem is gradually followed by intact, non-collapsed phloem, where there are no sclereid masses or crystals. The cells are in regular radial rows. The sieve tubes are wide and polygonal; the phloem rays are narrow and have squarish cells. Phloem parenchyma cells have tannin deposition (Figure 3).

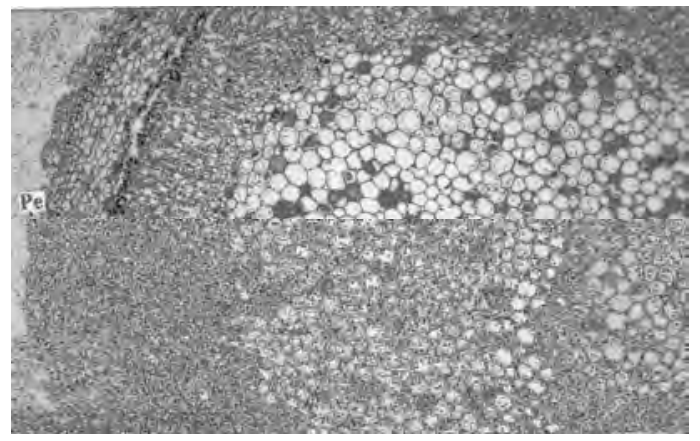

Figure 3: Anatomy of the stem - a sector of the transverse section of stem (Co $=$ cortex; $P e=$ periderm (phellem cells); $\mathrm{Pi}=$ pith; $\mathrm{SPh}=$ secondary phloem; $S X=$ secondary $x y l e m$ )

\section{Powder characteristics}

\section{Leaf powder}

Fragments of leaf are found in the powder. They exhibit certain specific characters of diagnostic values. Two types of epidermal trichomes were observed with powder. Scattered on the surface of the lamina are club-shaped, multicellular, stalked glands. They have unicellular, rectangular stalk cells 
and bi-seriate, wider body cells. The glands are $60 \mu \mathrm{m}$ in height and $25 \mu \mathrm{m}$ thick. Their distribution on the lamina is random. The cells of the epidermis from which the glandular trichomes arise are not modified in any way. These trichomes occur both on the veins and along the epidermal surface. They are multicellular, three- or four-celled, uniseriate and unbranched trichomes. The cells are narrow, long, thin- and smooth walled; the trichome is slender and mostly lopsided. They are up to $500 \mu \mathrm{m}$ long and $10 \mu \mathrm{m}$ thick. Fragments of abaxial epidermis are seen in the powder and they are stomatiferous. The epidermal cells have thin, wavy, anticlinal walls, rendering the cells amoeboid outline. The stomata are of anomocytic type. The guard cells are elliptical, wide and thinwalled.

\section{Stem powder}

The stem powder contains fibres, vessel elements and xylem parenchyma cells. The fibres are of libri-form type, having thick lignified walls and uni-seriate slit-like pits. The fibres are 300-500 $\mu \mathrm{m}$ long and $20 \mu \mathrm{m}$ thick. Vessel elements are unique in being long, narrow and thin walled. They resemble the fibres in length and width. However, the vessels have uni-seriate, scalariform, lateral, wall pits, and a long and much oblique scalariform perforation plate. The vessel elements are 800 - $900 \mu \mathrm{m}$ long and $40 \mu \mathrm{m}$ wide.

\section{Bark powder}

The bark powder contains abundance of sclereids. They are brachysclereids (stone cells) and vary in shape. Some of them are isodiametric and others are rectangular with unequal sides. The sclereids have thick walls and wide lumen. The walls have wide simple pits that are equal in size. Libriform fibres are also occasionally seen in the powder. They resemble the fibres in the stem. The bark fibres are up to $1.1 \mathrm{~mm}$ long, fairly thickwalled and have a single vertical row of pits.

\section{Physicochemical characteristics of the leaf and stem}

Hitochemical analysis of the leaf and stem revealed the presence of starch grains, lignins, saponins and phenolic compounds, but suberin and calcium oxalate crystals were found only in the bark. In the case of leaves, the quantity of alcohol extractive was higher than the aqueous extractive (Table 1). In the case of the stem, the water-soluble extractive was higher than the alcohol-soluble extractive. The loss on drying of the leaves and stem was $6.62 \pm 0.12$ and $6.12 \pm 0.15 \%$ $\mathrm{w} / \mathrm{w}$ respectively. The crude fibre content of the stem was $4.50 \pm 0.15 \% \mathrm{w} / \mathrm{w}$.

The sulphated ash value of the leaf and stem was higher than the total ash values of the stem and leaf in each case. On the other hand, the water-soluble and acid-insoluble ash values were lower than the total ash value of stem and leaf. However, the total ash value of the stem was lower than the water-soluble ash value of same part. This is unusual and may be due to incomplete conversion of a large quantity of alkali halides to oxides and carbonates.

The grains were rarely and randomly distributed. The presence of alkaloids was not evident in both the leaf and stem. The druses and grains of the bark measured up to $25 \mu \mathrm{m}$ and $15 \mu \mathrm{m}$ in diameter, respectively. The stone cells were frequent and most of them were isodiametric with a dimension up to $65 \mu \mathrm{m} \times 45 \mu \mathrm{m}$.

Powder characteristics of significant diagnostic value were studied for their frequency and dimensions (size ranges). The stomatal number was higher in the mid region of the lamina rather in the base and apex region. The palisade ratio determined from 10 randomly selected leaf fragments showed a mean of 5 cells/epidermal cell. The length of the covering trichomes ranged from $300-$ $550 \mu \mathrm{m}$ with a mean width of $8 \mu \mathrm{m}$ width at the broadest region. The glandular trichomes 
Table 1: Physicochemical analysis and micrometrics of the leaf and stem of Viburnum erubescens

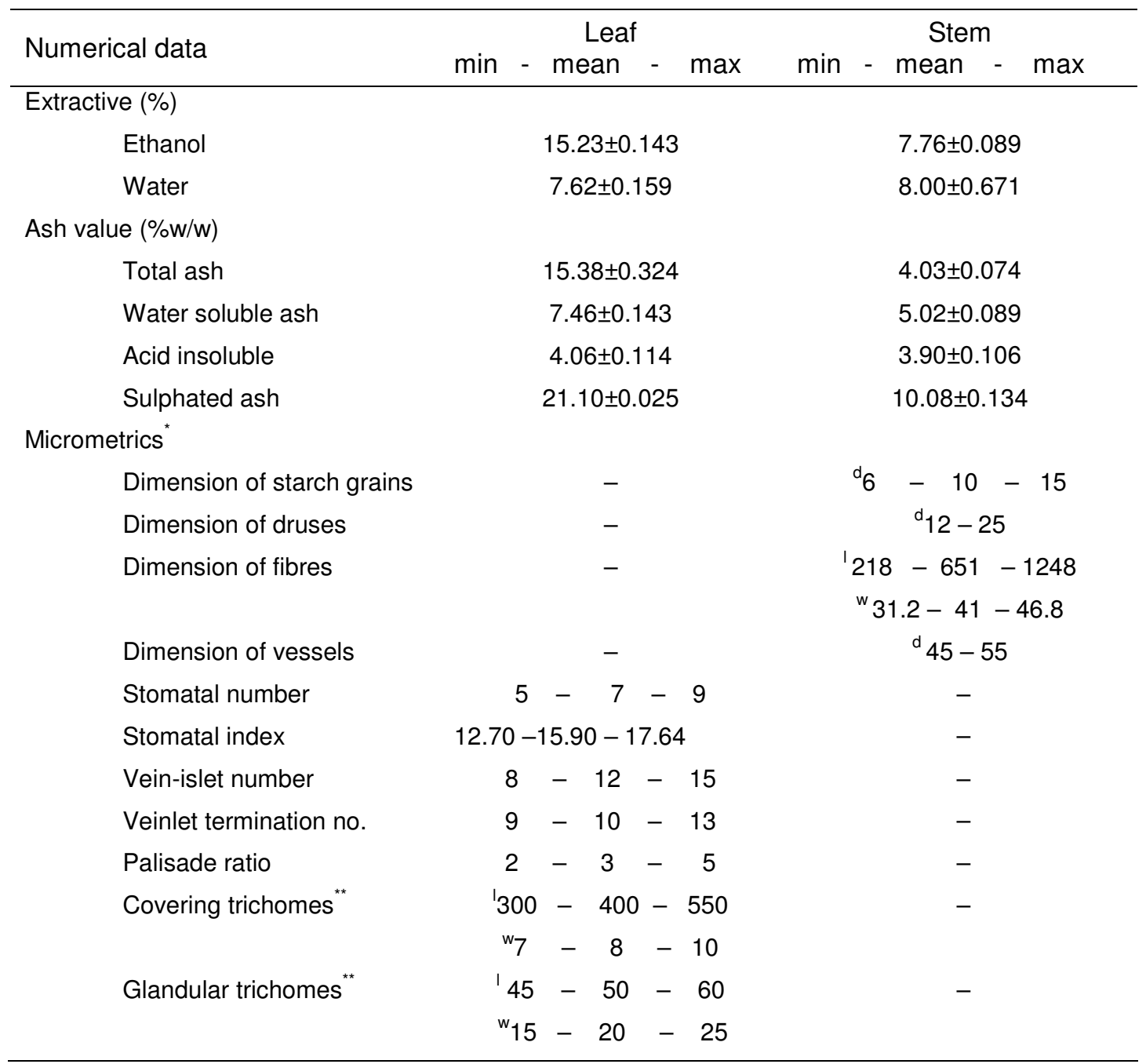

Results are presented as mean \pm standard deviation; $d=$ dimension in $\mu \mathrm{m}, \mathrm{I}=$ length in $\mu \mathrm{m}, w=$ width at the point of broader region in $\mu \mathrm{m} ;{ }^{*}=$ range obtained from the mean of 10 measurements; ${ }^{*}=$ size range obtained from measurement of 25 individual components

measured up to $60 \mu \mathrm{m}$ long and $25 \mu \mathrm{m}$ thick (base width) (see Table 1).

The leaf and stem extractives obtained with benzene and ethanol (95\%) were higher than those derived with petroleum ether (b.p., $60-80 \stackrel{\circ}{\circ}$ ), chloroform and water. Qualitative chemical analysis of the successive extracts revealed the presence of triterpenoids, sterols with non-polar fractions, glycosides, phenolic compounds and sugar with alcohol and aqueous fractions (Table 2). The various solvent leaf extracts and the leaf powder treated with acids and bases did not show any specific fluorescence. However, a transition in colours was observed. Only the aqueous extract of the bark which were similarly treated gave an orange fluorescence.

Trop J Pharm Res, December 2009; 8 (6):564 
Table 2: Extractives (\%), fluorescence analysis, and preliminary phytochemical screening of leaves and stem of Viburnum erubescens. Results are presented as mean \pm standard deviation; + = test is positive; $=$ test is negative

\begin{tabular}{|c|c|c|c|c|c|c|c|c|}
\hline $\begin{array}{l}\text { Solvent } \\
\text { Extract }\end{array}$ & $\% w / w$ & Fluorescence & 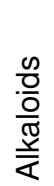 & $\frac{\frac{\omega}{0}}{\frac{0}{0}}$ & 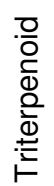 & $\begin{array}{l}\bar{\sigma} \\
\stackrel{D}{D} \\
\text { ஸ }\end{array}$ & 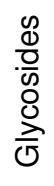 & $\begin{array}{l}\text { OO } \\
\frac{.0}{0} \\
\frac{C}{0} \\
\frac{C}{\alpha}\end{array}$ \\
\hline \multicolumn{9}{|c|}{$\begin{array}{l}\text { Petroleum ether } \\
\left(60-80^{\circ} \mathrm{C}\right)\end{array}$} \\
\hline Leaf & $1.87 \pm 0.078$ & Blackish green & - & + & + & - & - & - \\
\hline Stem & $2.49 \pm 0.071$ & Pale yellow & - & + & - & - & - & - \\
\hline \multicolumn{9}{|l|}{ Benzene } \\
\hline Leaf & $4.21 \pm 0.067$ & Black & - & + & + & - & - & - \\
\hline Stem & $5.71 \pm 0.078$ & Golden yellow & - & + & + & - & - & - \\
\hline \multicolumn{9}{|l|}{ Chloroform } \\
\hline Leaf & $2.11 \pm 0.071$ & Grey & - & + & + & - & - & - \\
\hline Stem & $1.81 \pm 0.085$ & Golden yellow & - & + & -- & - & - & - \\
\hline \multicolumn{9}{|l|}{ Ethanol (95\%) } \\
\hline Leaf & $5.93 \pm 0.067$ & Violet & - & - & - & + & + & + \\
\hline Stem & $2.99 \pm 0.078$ & Dark red & - & - & - & + & + & + \\
\hline \multicolumn{9}{|l|}{ Water } \\
\hline Leaf & $3.22 \pm 0.057$ & Pale orange & - & - & - & + & + & + \\
\hline Stem & $3.41 \pm 0.077$ & Fluorescent orange & - & - & - & + & + & + \\
\hline
\end{tabular}

\section{DISCUSSION}

The main objective of the current study was to evaluate the leaf and stem of Viburnum erubescens pharmacognostically in order to obtain and record some reproducible and precise parameters for the plants since the phytochemical constituents and pharmacological potential of the species have been reported in the literature. The genus comprises about 200 species growing as small shrubs and medium sized evergreen trees with comparable and confusing morphological appearances.

The quantity of alcohol extractive was higher than the aqueous extractive (see Table 1) and this may be attributed to the larger amount of alcohol-soluble constituents such as glycosides, flavonoids and phenolic compounds.

Some pharmacognostical parameters and preliminary phytochemical analysis of the root of another species, Viburnum nervosum, have been reported in the literature [16]. However, the present study is the first, to the best of our knowledge, to describe the pharmacognostical features of $V$. erubescens, in particular, its leaf and stem. The presence of triterpenoids, phenolic compounds and saponins in the root of $\mathrm{V}$. nervosum had previously been reported [16]. It is significant that the same phytochemicals were also found in the leaf and stem of V.erubescens in this study.

\section{CONCLUSION}

The pharmacogno - anatomical, physicochemical and powder characteristics of the leaf and stem of a plant may be useful in identifying plant species in whole and powder form. These data and parameters have been obtained for $V$. erubescens, Preliminary phytochemical studies revealed the presence of phytoconstituents such as triterpenoids, phenolic compounds, glycol- 
sides and saponins. Benzene and ethanol $(95 \%)$ soluble fractions of the species extract will need to be subjected to further phytochemical investigation, including bioactivity-directed chromatographic separation of the extracts.

\section{ACKNOWLEDGEMENT}

We pay our respects to late Dr Yogesh Mohan, Department of Pharmaceutics, IT$\mathrm{BHU}$, who suggested the species for this study. Also, we express our gratitude to the management of our institution for providing the facilities used.

\section{REFERENCES}

1. Gamble JS. Flora of the Presidency of Madras, Calcutta, India Botanical Survey of India; 1935; pp 1916-1936.

2. The Wealth of India. A Dictionary of Indian Raw materials and Industrial Products - Raw Material Series. New Delhi: Publication and Information Directorate, CSIR, 2003; pp 437 446.

3. Nadkarni $K M$. Indian Materia Medica. $2^{\text {nd }}$ ed. Bombay, India, Popular Prakashan, 2002; pp $1271-1272$
4. Johansen DA. Plant Microtechnique. New York, McGraw Hill Book Co., pp 1940; p 523.

5. Sass JE. Elements of Botanical Microtechnique. New York, McGraw Hill Book Co., 1940; $p 222$.

6. Easu K. Plant Anatomy. New York, John Wiley and Sons, 1964; $p 767$.

7. Henry AN, Kumari GR, Chitra V: Flora of Tamilnadu. Coimbatore, India, Botanical Survey of India, Southern Circle 1987; pp 1-3.

8. Pharmacopoeia of India. Ministry of Health and Family Welfare. New Delhi, The Controller of Publications, 1996; pp A47-A89.

9. O'Brien TP, Feder N, McCull ME. Polychromatic staining of plant cell walls by toluidine blue-O. Protoplasma 1964; (59): 364 - 373.

10. World Health Organization. Quality control methods for medicinal plant materials. WHO/PHARM/92.559, 1992; pp $11-36$.

11. Lala PK. Practical Pharmacognosy. India, Lina Guha Publication, 1981; pp 136-153.

12. Evans WC, Pharmacognosy, $15^{\text {th }}$ ed, W.B. Saunders, London ,2002; pp 516-545...

13. Wallis TE. Text Book of Pharmacognosy. $5^{\text {th }}$ ed, New Delhi, India, CBS Publishers and Distributors, 2005; pp 559 - 618 .

14. Khandelwal KR. Practical Pharmacognosy Techniques and Experiments. India, Nirali Prakashan, 2006; pp 15-163.

15. Harbone JB. Phytochemical methods, $3^{\text {rd }}$ ed, London, Chapman and Hall, 2005; pp 49-244.

16. Wahi AK. Khosa RL, Mohan Y, Pharmacognostical studies on the roots of Viburunum nervosum. Hook Bulle. Medico-ethnobotanical Res, 1981; 3: 205 